\title{
Kepatuhan dan Ketepatan Tenaga Medis dalam Pengisian Assessment Pre Dialisis di Klinik Hemodialisis Nitipuran Health Center
}

\author{
Raditya Priambodo ${ }^{1}$, Elsye Maria Rosa ${ }^{2}$, Sri Sundari $^{3}$ \\ ${ }^{1,2,3}$ Magister Manajemen Rumah Sakit, Pascasarjana, Universitas Muhammadiyah Yogyakarta \\ Jl.Brawijaya, Taman tirto Kasihan Bantul, 55183 \\ Correspondence e-mail: radityambodo@gmail.com
}

\begin{abstract}
Abstrak. Latar Belakang: Standar Nasional Akreditasi Rumah Sakit (SNARS) menyebutkan bahwa salah satu indikator kunci dalam standar pelayanan berfokus pasien adalah asesmen pasien. Tujuan penelitian ini adalah menganalisis tingkat kepatuhan dan ketepatan tenaga medis dalam pengisian assessment pre dialisis di NHC. Penelitian ini menggunakan mixed method dengan pendekatan Cohort Study prospective. Subjek penelitian adalah rekam medis untuk data kuantitatif dan dokter, perawat dan kepala perawat untuk data kualitatif. Analisis data kuantitatif dengan analisis deskriptif, dan analisis kualitatif dengan wawancara lebih mendalam. Hasil. Tingkat kepatuhan dan ketepatan tenaga medis dalam pengisian assessment pre dialisis di Klinik Hemodialisa Nitipuran belum cukup baik. Pelaksanaan pengisian assessment pre dialisis meliputi status fisik, riwayat kesehatan, riwayat alergi obat, asssesmen nyeri, risiko jatuh, dan kebutuhan edukasi. Kendalanya meliputi keterbatasan waktu, asesmen langsung diisi tanpa memeriksa dengan detail, adanya kekosongan pada catatan monitoring per jam. Kesimpulan. Kepatuhan dan ketepatan tenaga medis dalam mengisi assessment pre dialisis belum cukup baik, hal yang harus diperbaiki seperti pemberian waktu tambahan untuk memeriksa pasien, penggunaan alat tambahan seperti rekam medis elektronik.
\end{abstract}

Kata kunci: assessment; hemodialisis; tenaga medis

Abstract. Background: The National Hospital Accreditation Standards (SNARS) state that one of the key indicators in patientfocused service standards is patient assessment. The purpose of this study was to analyze the level of compliance and accuracy of medical personnel in pre dialysis assessments at NHC. Subjects and Method: This study uses a mixed method with the Cohort Study approach. Research subjects were medical records for quantitative data and doctors, nurses and head nurses for qualitative data. Quantitative data analysis with descriptive analysis, and qualitative analysis with in-depth interviews. Result: The level of compliance and accuracy of medical personnel in filling the pre dialysis assessment at the Nitipuran Hemodialysis Clinic is not quite good. The implementation of pre dialysis assessment at the NHC includes physical status, medical history, history of drug allergy, assessment of pain, risk of falls, and educational needs. Constraints include time constraints, assessments are filled in immediately without checking in detailly, there are gaps in the hourly monitoring records. Conclusion: compliance and accuracy of medical personnel in filling out assessments must be improved.

Keywords: assessment; hemodialysis; medical personnel

\section{PENDAHULUAN}

Standar Nasional Akreditasi Rumah Sakit (SNARS) menyebutkan bahwa salah satu indikator kunci dalam standar pelayanan berfokus pasien adalah asesmen pasien. Tujuan asesmen pasien yang efektif adalah untuk menghasilkan keputusan tentang kebutuhan asuhan pasien, pengobatan yang harus segera dilakukan dan pengobatan berkelanjutan untuk keadaan emergensi, elektif atau pelayanan terencana, bahkan ketika kondisi pasien berubah (SNARS, 2018).

Ruang Hemodialisa adalah salah satu unit kesehatan yang terdapat di Rumah Sakit dan memiliki standar Pelayanan tersendiri. Di Indonesia pada tahun 2009 tercatat sebanyak 5.450 pasien gagal ginjal yang menjalankan hemodialisa.

Hemodialisa merupakan terapi pengganti ginjal yang dilakukan 2-3 kali seminggu dengan lama waktu 45 jam, yang bertujuan untuk mengeluarkan sisa-sisa metabolisme protein dan mengoreksi gangguan keseimbangan cairan dan elektrolit (Black \& Hawk, 2005; Ignatavicius \& Workman, 2006).
Klinik Hemodialisis Nitipuran Health Center merupakan kilinik yang berfokus pada pelayan tindakan dialisis yang bergerak diluar dari institusi rumah sakit. Jumlah pasien rutin hemodialisis yang tercatat hingga Agustus 2019 berjumlah 152 pasien, jumlah total tindakan selama bulan juli 2019 tercatat sebanyak 1219 tindakan hemodialisis.

Borden \& Horowitz (2008) mendefinisikan kepatuhan sebagai sebuah proses pengaruh sosial dimana seseorang mengubah tingkah lakunya dalam menanggapi perintah langsung dari seseorang yang berwenang.

Standar Pelayanan pasien hemodialisa mencakup identifikasi pasien secara tepat, skrining awal untuk penyakit bawaan baik pasien baru maupun per 3-6 bulan untuk pasien lama, pemberian informed consent sebelum tindakan, dilakukan asesmen awal setiap pasien yang mencakup pemeriksaan fisik, lab, psikologis, nutrisi, riwayat pengobatan. Dilakukan asesmen lanjutan setiap dilakukan tindakan dan saat kondisi pasien terjadi perburukan, temuan dari asesmen didokumentasikan dalam rekam medis dan bertujuan untuk meminimalisir 
komplikasi dan memastikan dialisis adekuat (Tatik, 2018).

Penelitian ini hanya dilakukan pada assessment pasien yang menjalani perawatan hemodialisa di klinik NHC.

Tujuan penelitian ini adalah untuk:

1. Menganalisis kepatuhan pelaksanaa assessment pre dialisis pasien di Klinik Hemodialisis Nitipuran Health Center.

2. Menganalisis ketepatan pelaksanaa assessment pre dialisis pasien di Klinik Hemodialisis Nitipuran Health Center.

3. Mengetahui hambatan dan faktor pendukung implementasi assessment pre dialisis pasien di Nitipuran Health Centre.

4. Memberikan rekomendasi untuk meningkatkan kepatuhan dan ketepatan pengisian assessmentpasien pre dialisis di Nitipuran Health Centre.

\section{METODE}

Penelitian ini merupakan penelitian dengan menggunakan desain cohort study prospective. Jenis penelitian ini adalah metode campuran atau mix method yang berisi pendekatan kualitatif dan kuantitatif. Penggunaan metode campuran ini diharapkan akan memberikan pemahaman yang lebih baik terhadap pertanyaan dan masalah penelitian daripada menggunakan satu jenis metode saja (Creswell, 2012). Data kuantitatif diperoleh dengan cara melakukan observasi dengan menggunakan rekam medis pasien di NHC pada bulan agustus 2019. Bertujuan untuk melihat kepatuhan dan ketepatan penggunaan assessment pre dialisis berdasarkan pedoman SNARS edisi 1. Data kualitatif diperoleh dengan cara melakukan deep interview yang bertujuan untuk mengevaluasi implementasi pengisian assessment pre dialisis pasien di NHC.

Penelitian ini dilakukan di Nitipuran Health Centre, yang beralamat di Jl. Nitipuran No. 183 B, RT 06 Dukuh Sonosewu Kelurahan Ngestiharjo Kecamatan Kasihan, Kabupaten Bantul, DIY. Pada penelitian dari segi data kuantitatif adalah rekam medis pasien rawat jalan yang menjalani hemodialisis, sedangkan dari segi data kualitatif adalah perawat, kepala perawat dan dokter.

Objek penelitian ini adalah proses implementasi assessment pre dialisis pasien di Nitipuran Health Centre. Populasi dalam penelitian ini adalah dokumen dan petugas yang mengimplementasikan rekam medis pasien yang melakukan hemodialisis selama bulan agustus 2019. Sampel menggunakan rumus Slovin didapatkan jumlah sampel sejumlah 305. Dari segi wawancara menggunakan purposive sampling.

Instrumen yang digunakan dalam pendekata kualitatif adalah assessment pre dialisis pasien yang menjalani hemodialisis. Instrumen penelitian yang digunakan dalam pendekatan kuantitatif adalah sebagai berikut:

a) Lembar panduan wawancara yang merupakan daftar pertanyaan yang akan diajukan kepada responden penelitian.

b) Alat dokumentasi, yaitu alat yang dapat digunakan untuk merekam hasil wawancara terhadap responden penelitian.

Secara garis besar pada penelitian ini dilakukan dua proses pengumpulan data yaitu observasi dan wawancara yang dilakuakan sesuai dengan panduan masing-masing. Dilakukan dengan analisis deskriptif terhadap observasi untuk mengetahui kepatuhan pendokumentasian terhadap assessment pre dialisis pasien, kemudian data diolah dengan menggunakan program computer.

Hasil pelaksanaan evaluasi kepatuhan dan ketepatan assessment pre dialisis yang diteliti oleh peneliti disesuaikan dengan kondisi faktual yang terjadi di lapangan dengan melakukan wawancara lebih mendalam untuk mengklarifikasi implementasi assessment pre dialisis pasien. Proses penarikan kesimpulan dilakukan dengan analisis Miles dan Huberman. Analisis ini terdiri dari tiga hal utama, yaitu reduksi data yang diartikan sebagai proses pemilihan, pemusatan, atau penyederhanaan dari catatan lapangan. Penyajian data, yaitu sebuah usaha untuk menyusun skumpulan informasi pada suatu matrik yang mudah dipahami.Penyajian data dalam penelitian ini dilakukan secara tekstual dan table. Yang terakhir adalah penarikan kesimpulan yaitu proses pengumpulan data yang diperoleh untuk mendapatkan kesimpulan yang komprehensif

\section{HASIL DAN PEMBAHASAN \\ Hasil}

\section{Kepatuhan dan Ketepatan Assessment Pre Dialisis}

Berikut persentase kepatuhan dan ketepatan assessment tenaga medis dalam mengisi assessment pre dialisis di unit Hemodialisars Klinik Hemodialisa Nitipuran

Tabel 1. Deskripsi Kepatuhan Tenaga Medis dalam Mengisi Assessment Pre Dialisis di NHC

\begin{tabular}{cccc}
\hline No & Assessment Pre-Dialisis & f & \% \\
\hline 1. & Status fisik & & \\
& a. Patuh & 305 & 100,0 \\
& b. Tidak patuh & 0 & 0,0 \\
Jumlah & 305 & 100,0 \\
2. Riwayat kesehatan & & \\
& a. Patuh & 20 & 7,0 \\
& b. Tidak patuh & 285 & 93,0 \\
& $\quad$ Jumlah & 305 & 100,0 \\
3. Riwayat alergi obat & & \\
& a. Patuh & 130 & 42,7 \\
& b. Tidak patuh & 175 & 57,3 \\
& $\quad$ Jumlah & 305 & 100,0
\end{tabular}


Raditya Priambodo et al, Kepatuhan dan Ketepatan Tenaga Medis dalam Pengisian Assessment Pre Dialisis di Klinik Hemodialisis Nitipuran Health Center

4. Assessment nyeri
a. Patuh
67
b. Tidak patuh Jumlah
a. Patuh
238
305
21,9
78,1
100,0
283
92,7
7,3 Jumlah
22
305
100,0

5. Resiko jatuh

6. Kebutuhan edukasi

\begin{tabular}{|c|c|c|}
\hline a. Patuh & 294 & 96,3 \\
\hline b. Tidak patuh & 11 & 3,4 \\
\hline Jumlah & 305 & 100,0 \\
\hline
\end{tabular}

Tabel di atas memberikan hasil bahwa tingkat kepatuhan pengisian assessment pre dialisis berdasarkan rekomendasi SNARS tertinggi ada pada bagian pemeriksaan status fisik sebesar $100 \%$, selanjutnya untuk pengisian daftar riwayat kesehatan hanya $7 \%$, pengisian riwayat alergi obat sebesar $42,7 \%$, pengisian asesmen nyeri sebesar $21,9 \%$, penilaian resiko jatuh pada pasien sebesar $92,7 \%$, serta pengisian kebutuhan edukasi sebesar $96,3 \%$.

ketepatan pengisian assessment pre dialisis dari segi penilain berat badan pada status fisik masih sebagian besar belum terisi sabanyak 107 (35,3\%), pengisian akses vaskuler pada status fisik juga masih belum banyak terisi yaitu 271 (11\%), dan pengisian resiko jatuh yang lengkap hanya $74(24,4 \%)$.

\section{Hambatan Implementasi Assessment Pre Dialisis Pasien} Di NHC

Tabel 2. Deskripsi Kendala Pengisian Assessment

\begin{tabular}{|c|c|c|}
\hline Tema & Kode & Interpretasi \\
\hline Kendala & $\mathrm{D}$ & Keterbatasan waktu \\
\hline $\begin{array}{l}\text { Pengisian } \\
\text { Assessment }\end{array}$ & $\operatorname{Pr}$ & $\begin{array}{l}\text { SOP langsung diisi semua tanpa } \\
\text { memeriksa dengan detail karena } \\
\text { sudah hafal }\end{array}$ \\
\hline & Ka.Pr & $\begin{array}{l}\text { Terjadi kekosongan pada catatan } \\
\text { monitoring per jam }\end{array}$ \\
\hline
\end{tabular}

Tabel di atas menunjukkan bahwa tenaga medis Klinik Hemodialisa Nitipuran menyatakan bahwa masih ada kendala yang ditemui dalam pengisian assessment. Kendala tersebut antara lain:

1. Keterbatasan waktu pemeriksaan

2. Asesmen langsung diisi semua tanpa memeriksa dengan detail karena perawat sudah hafal.

3. Terjadi kekosongan pada catatan monitoring per jam pada pengisian asesmen.

Rekomendasi untuk meningkatkan kepatuhan dan ketepatan pengisian assessmentpasien pre dialisis di Nitipuran Health Centre
Tabel 3. Deskripsi Harapan Kedepan terkait Implementasi Assessment

\begin{tabular}{ccl}
\hline Tema & Kode & \multicolumn{1}{c}{ Interpretasi } \\
\hline Harapan & $\mathrm{D}$ & Adanya spare waktu yang ideal \\
& $\mathrm{Pr}$ & Assessment diisi secara runtut dan benar \\
& $\mathrm{Ka}$.Pr & Menggunakan EMR \\
\hline
\end{tabular}

Tabel di atas menunjukkan bahwa tenaga medis Klinik Hemodialisa Nitipuran memiliki harapan bahwa kedepannya diperlukan tambahan waktu bagi dokter dalam melakukan assessment kepada pasien, serta pengisian assessment yang runtut dan benar dan digunakannya rekam medic elektronik.

\section{Pembahasan}

Hasil penelitian menunjukkan bahwa assessment pre-dialisis yang sudah dilakukan dengan patuh oleh tenaga medis paling banyak adalah status fisik, yaitu sebanyak $100 \%$ sedangkan yang paling sedikit adalah riwayat kesehatan yang hanya sebanyak $7 \%$.

Assessment merupakan suatu kegiatan yang dilakukan secara sistematis untuk mendapatkan informasi dari pasien untuk merencanakan tindakan selanjutnya. Assessment pasien menjadi salah satu indikator pokok dalam standar pelayanan yang berfokus pada pasien. Seperti yang diungkapkan oleh SNARS (2018) yang menyebutkan bahwa assessment bertujuan untuk menghasilkan keputusan tentang kebutuhan asuhan pasien, pengobatan yang harus segera dilakukan dan pengobatan berkelanjutan untuk keadaan emergensi, elektif atau pelayanan terencana, bahkan ketika kondisi pasien berubah. Assessment pre-dialisis dilakukan terhadap pasien yang mengalami gagal ginjal. Menurut Tatik (2018) dalam seminar Standar Mutu Pelayanan Pasien HD Instalasi Dialisis RSUP Dr. Sardjito disebutkan bahwa standar pelayanan pasien hemodialisa mencakup identifikasi pasien secara tepat, skrining awal untuk penyakit bawaan baik pasien baru maupun per 3-6 bulan untuk pasien lama, pemberian informed consent sebelum tindakan, dilakukan asesmen awal setiap pasien yang mencakup pemeriksaan fisik, lab, psikologis, nutrisi, riwayat pengobatan. Dilakukan asesmen lanjutan setiap dilakukan tindakan dan saat kondisi pasien terjadi perburukan, temuan dari asesmen didokumentasikan dalam rekam medis dan bertujuan untuk meminimalisir komplikasi dan memastikan dialisis adekuat.

Menurut hasil penelitian, pelaksanaan pengisian assessment pre dialisis di Klinik Hemodialisa Nitipuran meliputi status fisik, riwayat kesehatan, riwayat alergi obat, asssesmen nyeri, risiko jatuh, dan kebutuhan edukasi. Hal ini menunjukkan bahwa pengisian assessment pre dialysis belum semuanya dilakukan. Seperti yang tercantum dalam SNARS (2018) bahwa assessment awal pre dialisis meliputi status fisik, psiko sosial spiritual, ekonomi, riwayat kesehatan, riwayat alergi obat, assessmen nyeri, risiko jatuh, assessmen 
fungsional, risiko nutrisional, kebutuhan edukasi dan perencanaan pemulangan pasien.

Berdasarkan hasil penelitian di atas, maka kepatuhan dan ketepatan tenaga medis dalam mengisi assessment pre-dialisis di Klinik Hemodialisa Nitipuran belum cukup baik. Hal ini dikarenakan belum semua assessment dilakukan secara tepat. Hasil penelitian menunjukkan bahwa hanya terdapat satu indikator yang sudah dilakukan dengan tepat $(100 \%)$ yaitu pemeriksaan terhadap status fisik pasien. Sedangkan uuntuk pemeriksaan terhadap resiko jatuh, baru mencapai $92,7 \%$ dan pemberian edukasi kepada pasien mencapai 96,3\%. Hasil ini mengindikasikan bahwa belum semua tenaga medis melakukan pengisian assessment pre-dialisis dengan tepat.

Hasil penelitian juga menunjukkan bahwa terdapat tiga indikator yang mempunyai persentase kepatuhan rendah, yaitu riwayat kesehatan sebesar $7 \%$, riwayat alergi obat sebesar $42,7 \%$ dan assessmen nyeri sebesar $21,9 \%$. Hal ini menunjukkan bahwa poin tersebut masih sering terlalaikan.

Rendahnya persentase kepatuhan dalam pengisian assessment pre-dialisis disebabkan karena masih adanya kendala atau hambatan dalam proses pengisian assessment tersebut. Berikut ini masalah dan hambatan dalam implementasi pengisian assessment pre-dialisis pasien di Klinik Hemodialisa Nitipuran:

1. Keterbatasan waktu bagi dokter dalam melakukan assessment

2. Standar prosedur operasional belum disosialisasikan ke dokter dan tidak dijalankan dengan benar, asesmen langsung diisi semua tanpa memeriksa dengan detail karena perawat sudah hafal.

3. Terjadi kekosongan pada catatan monitoring per jam. Untuk mengatasi masalah tersebut, perlu dilakukan evaluasi terhadap pelaksanaan assessment selama ini. Walaupun evaluasi sudah dilaksanakan, namun belum semuanya terlaksana, sehingga belum bisa melihat pelaksanaan pengisian assessment secara keseluruhan.

Rekomendasi dalam pelaksanaan assessment pre dialisis di Klinik Hemodialisa Nitipuran antara lain adanya tambahan waktu bagi dokter dalam melakukan assessment, assessment diisi secara runtut dan benar serta penggunaan rekam medis elektronik dalam pengisian assessment untuk menghindari kekosongan pada catatan per jam.

\section{SIMPULAN}

Berdasarkan hasil penelitian dan pembahasan, dapat ditarik kesimpulan sebagai berikut: Tingkat kepatuhan dan ketepatan tenaga medis dalam pengisian assessment pre dialisis di Klinik Hemodialisa Nitipuran belum cukup baik. Pelaksanaan pengisian assessment pre dialisis di Klinik Hemodialisa Nitipuran meliputi status fisik, riwayat kesehatan, riwayat alergi obat, asssesmen nyeri, risiko jatuh, dan kebutuhan edukasi.
Masalah dan hambatan dalam implementasi pengisian assessment pre-dialisis pasien di Klinik Hemodialisa Nitipuran: Keterbatasan waktu bagi dokter dalam melakukan assessment. Asesmen langsung diisi semua tanpa memeriksa dengan detail karena perawat sudah hafal. Terjadi kekosongan pada catatan monitoring per jam.

Rekomendasi untuk meningkatkan kepatuhan dan ketepatan pengisian assessmen pre dialisis antara lain: Adanya tambahan waktu bagi dokter dalam melakukan assessment. Assessment diisi secara runtut dan benar . Digunakannya kembali rekam medis elektronik dalam pengisian assessment untuk menghindari kekosongan pada catatan per jam.

\section{DAFTAR PUSTAKA}

Black, J.M.,\& Hawk, J.H. (2005). Medical Surgical Nursing : Clinical Management for Positive Outcome.7th edition.Philadelphia : W.B. Sounders Company

Borden, S.K., \& Horowitz, A.(2008). Sosial Psychology, 3th Edition.New York: The Free Press

Ignatavicius,D.D., \& Workman, M.L. (2006). Medical Surgical Nursing: Critical Thinking for Collaborative Care.5th edition.St Louis:Elsevier Saunders

SNARS. 2018. Standar Nasional Akreditasi Rumah Sakit Edisi 1. Jakarta: EGC.

Tatik Dwi Wahyuni. Instalasi Dialisis RSUP Dr. Sardjito: Seminar Standar Mutu Pelayanan Pasien Hemodialisa. Yogyakarta. 